\title{
WISATA SEPEDA DALAM MEWUJUDKAN PARIWISATA BERKELANJUTAN DI SANUR
}

\author{
Komang Wirawan \\ Email: mangkok.hitam@gmail.com
}

\begin{abstract}
Cycling tourism is a recreational activity in a vacation far from home or everyday life in which riding a bicycle constitutes the basic and significant part. Sanur, well-known by tourists as a holiday spot where bicycles are easy to find and commonly used as a transportation mode, has some potentials conducive to the development of cycling tourism. They have also been reinforced with the stakeholders' planning and activities in the hope that this type tourism activity can keep growing for the local people and tourists to eventually bring about sustainable tourism. The planning covers public policies, physical development for cyclists, the establishment of cycling lanes, the making of maps, and promotions that involve all stakeholders. This research was carried out by identifying potential based on the tourism components of 4-A of Attractions, Accessibility, Amenities, and Ancillary, available at Sanur are related to the development of cycling tourism. The research concludes that cycling tour has been developed in Sanur and has the potential to support the sustainability of the destination.
\end{abstract}

Keywords: cycling tourism, tourism components, sustainable tourism, Sanur.

\section{Pendahuluan}

Peningkatan jumlah kunjungan wisatawan ke suatu destinasi pariwisata berimbas pada penggunaan moda transportasi yang nantinya bermuara pada peningkatan konsumsi energi. Pariwisata khususnya dalam permasalahan di Bali yang sebagian besar industrinya berasal dari jasa pariwisata memiliki peran yang besar dalam pengendalian penggunaan energi menuju ke arah yang lebih efisien. Selain itu penggunaan nonrenewable energy (energi tidak terbarukan) menimbulkan polusi yang dapat berdampak pada penurunan kualitas lingkungan. Menurut Guiver (2008), ada beberapa cara untuk 
menurunkan dampak lingkungan akibat dari transportasi, yakni menurunkan jumlah perjalanan, menurunkan jarak perjalanan, menurunkan jumlah dari kendaraan dengan menggunakan transportasi masal, serta memindahkan perjalanan ke moda yang berkelanjutan seperti berjalan dan bersepeda.

Sepeda adalah salah satu moda transportasi yang ramah lingkungan yang bisa menjadi solusi dalam mengurangi dampak pariwisata terhadap lingkungan sekitar. Bersepeda menjadi kecenderungan berkegiatan pada dekade ini dengan semakin meningkatnya penjualan sepeda secara global. Pada dasarnya bersepeda diartikan oleh wisatawan sebagai bagian integral dari ekskursi atau liburan, cara yang menguntungkan demi meningkatkan kualitas waktu liburan (Lumsdon, 2000). Bersepeda dalam hal ini ditujukan untuk meningkatkan kualitas liburan bagi wisatawan di dalam suatu destinasi pariwisata. Bersepeda diyakini mampu mempercepat pergerakan wisawatan di dalam destinasi, menyehatkan, dan juga ramah lingkungan, selain itu juga bisa menurunkan penggunaan energi, polusi udara dan suara, efek rumah kaca, kemacetan, dan dampak lain yang ditimbulkan oleh kendaraan bermesin. Pucher dan Buehler (2012), berpendapat, mengurangi ketergantungan terhadap kendaraan bermesin, maka dengan bersepeda bisa meningkatkan keberlanjutan dari sistem transportasi. Dalam hal ini bersepeda bisa menjadi bentuk transportasi yang mendukung pariwisata di Bali. Salah satu bentuk dari penggabungan kegiatan bersepeda dan pariwisata adalah cycling tourism atau pariwisata bersepeda.

Broadaway (2012) mendefinisikan pariwisata bersepeda sebagai kunjungan rekreasi dalam satu malam atau jauh dari rumah (kehidupan sehari-hari), dimana bersepeda sebagai bagian mendasar dan bagian yang signifikan dari suatu liburan. Berdasar pengertian tersebut disebutkan bahwa bersepeda bukan sebagai atraksi tetapi lebih dari itu adalah bagian yang tidak terlepas sebagai sebuah sistem dalam berwisata di dalam destinasi tersebut.

Film "Eat, Pray, Love" (2010), diangkat dari kisah novel berjudul sama karya Elizabeth Gilbert terbitan tahun 2006, yang diperankan oleh Julia Roberts ikut serta dalam mengenalkan pariwisata bersepeda di Pulau Bali, karena ada banyak adegan yang menunjukkan pemeran utama mengendarai sepeda di tengah hijau sawah dan permukiman tradisional di Desa Ubud. Dalam tulisan novel, Gilbert menceritakan bagaimana baik dan buruk kondisi Ubud ketika melakukan aktivitas bersepeda.

Now I'm mobile in my new town of Ubud, or at least as mobile as I can safely feel on these roads, which are narrow and wind-ing and badly maintained and crowded with motorcycles, trucks and tourist buses (Gilbert, 2006: 232).

Gilbert menjelaskan ketidaknyamanan dan tidak merasa aman ketika 
bersepeda karena kondisi jalanan Ubud yang dipenuhi oleh sepeda motor, truk, dan bus pariwisata sekaligus. Di sisi lain Gilbert melukiskan bahwa Ubud adalah tempat menarik untuk bersepeda dengan gambaran mempunyai awan berwarna merah muda yang dipantulkan oleh air di bentangan sawah, seperti pernyataan selanjutnya:

In the evenings I spin my bicycle high up into the hills and across the acres of rice terraces north of Ubud, with views so splendid and green. I can see the pink clouds reflected in the standing water of the rice paddies, like there are two skies-one up in heaven for the gods, and one down here in the muddy wet, just for us mortals (Gilbert, 2006: 238).

Sanur adalah salah satu destinasi pariwisata di Bali di mana sepeda merupakan salah satu moda transportasi yang mulai banyak digunakan oleh wisatawan. Sepeda dengan mudah didapat oleh wisatawan, baik melalui persewaan sepeda maupun melalui hotel-hotel yang menyediakan sepeda gratis atau berbayar bagi tamu yang menginap. Selain sarana sepeda yang mudah didapat, Sanur juga didukung oleh kondisi topografi yang cenderung datar serta mempunyai pemandangan laut yang tenang.

Kondisi geografis tersebut juga didukung oleh kondisi budaya yang masih terjaga dengan baik, bisa terlihat dengan masih adanya areal persawahan yang asri dan juga permukiman tradisional Bali yang masih dihuni oleh penduduk lokal Sanur secara turun temurun. Sanur sebagai destinasi pariwisata yang menjadi cikal bakal pariwisata Bali juga didukung dengan akomodasi wisata yang bervariasi, dari home stay hingga hotel berbintang lima yang menjadikan Sanur sebagai destinasi pariwisata terpadu, yang lengkap dalam pemenuhan kebutuhan wisatawan.

Saat ini pengembangan moda transportasi sepeda di destinasi pariwisata Sanur sangat diperhatikan, mulai dari adanya jalur, lajur khusus sepeda, parkir sepeda, penyewaan sepeda oleh penduduk setempat di beberapa titik, adanya fasilitas sepeda gratis oleh beberapa hotel untuk tamu yang menginap. Berbagai fasilitas ini menyebabkan Sanur menjadi lokasi yang sangat nyaman untuk bersepeda. Bahkan perkembangan penggunaan sepeda di Sanur ini diperkuat dengan Peraturan Walikota Denpasar No 27 tahun 2011 tentang Rencana Tata Ruang Wilayah Kota Denpasar. Dalam pasal 19 dan 35 pada peraturan tersebut adanya ketentuan mengenai pemanfaatan sarana dan prasarana perkotaan dalam memprioritaskan pengguna sepeda melalui penyediaan jalur khusus sepeda. Hal tersebut juga diperkuat dengan adanya peraturan zonasi jalur sepeda, dimana Sanur termasuk di dalamnya. Sangat layak jika Destinasi Pariwisata Sanur sebagai bagian dari Kota Denpasar dikembangkan pariwisata bersepeda untuk menciptakan pariwisata berkelanjutan (green tourism). 


\section{Pariwisata Bersepeda dan Pariwisata Berkelanjutan}

Secara prinsip, pariwisata berkelanjutan adalah pariwisata yang memperhitungkan penuh dampak ekonomi, sosial, dan lingkungan saat ini dan masa depan, mengatasi kebutuhan wisatawan, industri, lingkungan dan masyarakat setempat (UNEP dan UNWTO, 2005). Dalam prinsip pariwisata berkelanjutan selalu mengedepankan lingkungan sebagai titik perhatian utama dalam aktivitas wisata yang terjadi di dalam destinasi. Dalam 12 tujuan dari pariwisata berkelanjutan, dua di antaranya adalah efisiensi sumberdaya dan pelestarian lingkungan. Efisiensi dilakukan dengan meminimalkan penggunaan sumber daya yang terbatas dan tidak terbarukan dalam pengembangan dan pengoperasian fasilitas dan layanan pariwisata. Dalam tujuan pelestarian lingkungan adalah dengan meminimalkan polusi udara, air dan tanah dan produksi limbah oleh industri pariwisata dan dari aktivitas wisatawan. Transportasi dalam kegiatan pariwisata memiliki peran penting dalam perjalanan wisata, disamping itu juga menyumbang polusi di dalam destinasi pariwisata akibat penggunaan energi tidak terbarukan oleh moda yang digunakan. Oleh sebab itu, transportasi menjadi fokus penting dalam pembangunan pariwisata saat ini.

Laporan United Nation Environment Programmed dan World Tourism Organitazion (UNWTO) pada tahun 2005 berjudul Making Tourism More Sustainable (Mewujudkan Pariwisata yang Lebih Berkelanjutan) menjelaskan bagaimana mewujudkan pariwisata berkelanjutan melalui kebijakan transportasi. Transportasi dalam industri pariwisata seperti diketahui memiliki pengaruh yang signifikan dalam pencemaran lingkungan, bersumber dari penerbangan dan penggunaan kendaraan bermotor pribadi.

Ada tiga kebijakan mengenai transportasi yang disarankan oleh UNWTO untuk dilaksanakan dalam mengambil kebijakan publik. Pertama, mempromosikan berjalan dan bersepeda di destinasi pariwisata, yang bisa difasilitasi dengan pemenuhan inftastruktur yang layak menyangkut rute dan pelayanan transportasi publik, perbanyak transportasi yang terintegrasi dan promosi yang kreatif dan memikat. Kedua, dengan meminimalkan jumlah dan jarak dari perjalanan wisata, secara nyata akan menurunkan pencemaran lingkungan, tetapi akan mempunyai dampak yang serius terhadap industri pariwisata dan untuk masyarakat lokal yang bergantung pada wisatawan. Kebijakan harus mencari celah untuk meningkatkan lama hunian wisatawan di destinasi pariwisata sehingga pengeluaran wisatawan tetap terjaga. Ketiga, pencegahan terhadap dampak terhadap lingkungan dari transportasi. Kampanye dapat dibangun yang mengundang wisatawan untuk mengimbangi dampak dari perjalanan udara, dengan berkontribusi terhadap proyek-proyek pengurangan karbon.

Sanur sebagai salah satu destinasi pariwisata utama di Kota Denpasar memiliki beberapa rencana program untuk meningkatkan kenyamanan 
wisatawan dalam konteks transportasi seperti pengalihan arus lalu lintas di sepanjang jalur utama, pembangunan sentral parkir untuk wisatawan dan pekerja beserta shuttle bus (Pantai Matahari Terbit dan Pantai Mertasari), perluasan jogging track di pantai dan trotoar di jalan utama untuk kenyamanan pejalan kaki, pembuatan jalur sepeda dan sarana pendukung, promosi penggunaan sepeda dan fasilitas transportasi publik perkotaan, dan pembuatan peta jalur sepeda untuk wisatawan.

Di dalam destinasi pariwisata Sanur sendiri usaha dalam pengalihan moda yang berkelanjutan untuk mengurangi masalah transportasi di dalam pariwisata sudah dilakukan dengan meningkatkan kenyamanan penjalan kaki dan pengguna sepeda. Usaha dilakukan seperti pembuatan jalur sepeda dan sarana pendukungnya seperti rambu sepeda, ruang tunggu, peta sepeda, oparkir sepeda, serta toilet dan shower. Promosi juga dilakukan dalam peningkatan pemanfaatan jalur sepeda tersebut oleh wisatawan. Selain pembangunan infrastruktur pengalihan arus lalu lintas di jalan utama di Destinasi Pariwisata Sanur terus dikaji untuk memberikan kenyamanan wisatawan dalam pergerakannya dalam berjalan ataupun menggunakan kendaraan. Usaha untuk mewujudkan Sanur sebagai destinasi yang ramah lingkungan dalam bidang transportasi memang harus terus dilakukan.

\section{Potensi Sanur untuk Pariwisata Bersepeda}

Destinasi pariwisata Sanur sejatinya adalah sebuah area/kawasan wisata yang telah berkembang baik sebagai sebuah destinasi pariwisata pantai yang mampu memberikan manfaat bukan hanya bagi wisatawan tetapi juga masyarakat Kota Denpasar dalam pemenuhan kebutuhan rekreasi di dalam kota. Selain itu juga untuk mencapai tujuan yang lebih besar yakni mewujudkan Sanur sebagai Kota Sepeda percontohan di Kota Denpasar dan lebih besar lagi menjadi Eco City (Kota yang Berkelanjutan).

Di destinasi pariwisata Sanur, terdapat beberapa potensi yang menjadikan Sanur sebagai destinasi pariwisata yang bisa dikembangkan dengan tujuan yakni sepeda sebagai moda transpotasi utama bagi wisatawan yang ingin mengunjungi / menjelajahi wilayah Sanur. Potensi ini dibagi dalam elemen $4 A$ yang dapat mendukung dalam pengembangan pariwisata sepeda di Destinasi Pariwisata Sanur yakni pertama Attractions suatu daerah/kawasan pariwisata pasti mempunyai daya tarik wisata berupa alam, masyarakat, beserta budayanya. Kedua Accessibility, dimaksudkan agar wisatawan dalam berkegiatan wisata dapat menjangkau dan mudah dalam pergerakan. Ketiga Amenities, adalah fasilitas untuk wisatawan maupun kegiatan berwisata sehingga wisatawan dapat merasakan kenyamanan dan betah berwisata di destinasi tersebut. Terakhir, keempat, Ancillary, adanya lembaga pariwisata untuk mengatur/mengelola atau juga sebagai pengawas dalam kegiatan pariwisata di destinasi pariwisata. 


\subsection{Attractions}

Dalam melihat Sanur sebagai sebuah destinasi pariwisata maka daya tarik wisata menjadi bagian mutlak dalam kegiatan pariwisata. Daya tarik dibedakan menjadi dua yakni daya tarik alam dan dan daya tarik buatan. Daya tarik alam yang menjadi andalan destinasi ini adalah pantai, sawah dan hutan bakau. Pantai di Sanur membentang sepanjang $9 \mathrm{~km}$ yang membuat Sanur memiliki akses pantai terpanjang yang bisa dilalui oleh publik dengan menggunakan sepeda di Bali (Foto 1). Persawahan umumnya ada di bagian barat yang merupakan ruang terbuka hijau perkotaan di Kota Denpasar sehingga keberadaannya terjaga secara legal, walau masih sering terjadi pelanggaran tata ruang. Hutan bakau berada di wilayah selatan dengan luas 7 hektar dan sangat sering digunakan untuk kegaiatan penanaman bibit mangrove. Kesemua daya tarik ini dapat diakses dengan menggunakan sepeda tanpa harus mengeluarkan biaya bagi wisatawan. Daya tarik buatan terdiri dari wisata bahari, permukiman tradisional, pura, pasar tradisional, pasar seni, peninggalan bersejarah, wisata kuliner, dan paket wisata sepeda. Daya tarik ini mendukung Destinasi Pariwisata Sanur sebagai destinasi yang ramah terhadap wisatawan bersepeda.

\subsection{Accessibility}

Aksesibilitas pantai yang terbuka menjadikan Sanur sebagai pantai yang bisa diakses oleh masyarakat umum, sehingga tidak ada pantai privat di destinasi ini. Hal ini menjadi daya tarik bagi wisatawan untuk bersepeda karena jangkauan sepeda yang luas di wilayah Sanur dibandingkan dengan kendaraan lain. Selain itu, fasilitas penunjang aksesibilitas kegiatan bersepeda ada di destinasi ini walaupun secara kualitas dan kuantitas masih sangat kurang. Fasilitas yang ada antara lain jalur sepeda, lajur sepeda, parkir, ruang transit/istirahat, kondisi jalan yang baik, rambu, informasi mengenai pariwisata bersepeda dan transportasi publik yang terintegrasi (bus Trans Sarbagita dan taksi) di Destinasi Pariwisata Sanur. Dari semua fasilitas ini akan mendukung pengembangan pariwisata bersepeda di dalam destinasi dan diharapkan Sanur menjadi destinasi pariwisata yang ramah, aman, dan nyaman terhadap pengendara sepeda.

\subsection{Amenities}

Sebagai sebuah resort pertama di Bali, tentunya Destinasi Pariwisata Sanur berkembang dengan fasilitas pariwisata yang memadai, seperti akomodasi, restoran dan toko untuk berbelanja wisatawan. Sayang, jumlah yang banyak ini hanya tersebar di wilayah timur dan dekat dengan pantai. Adanya jalur bersepeda yang melewati daerah barat Sanur menjadikan wilayah ini berkembang untuk kegiatan pariwisata. Adapun fasilitas yang mendukung dari pariwisata bersepeda terdiri dari fasilitas pendukung 


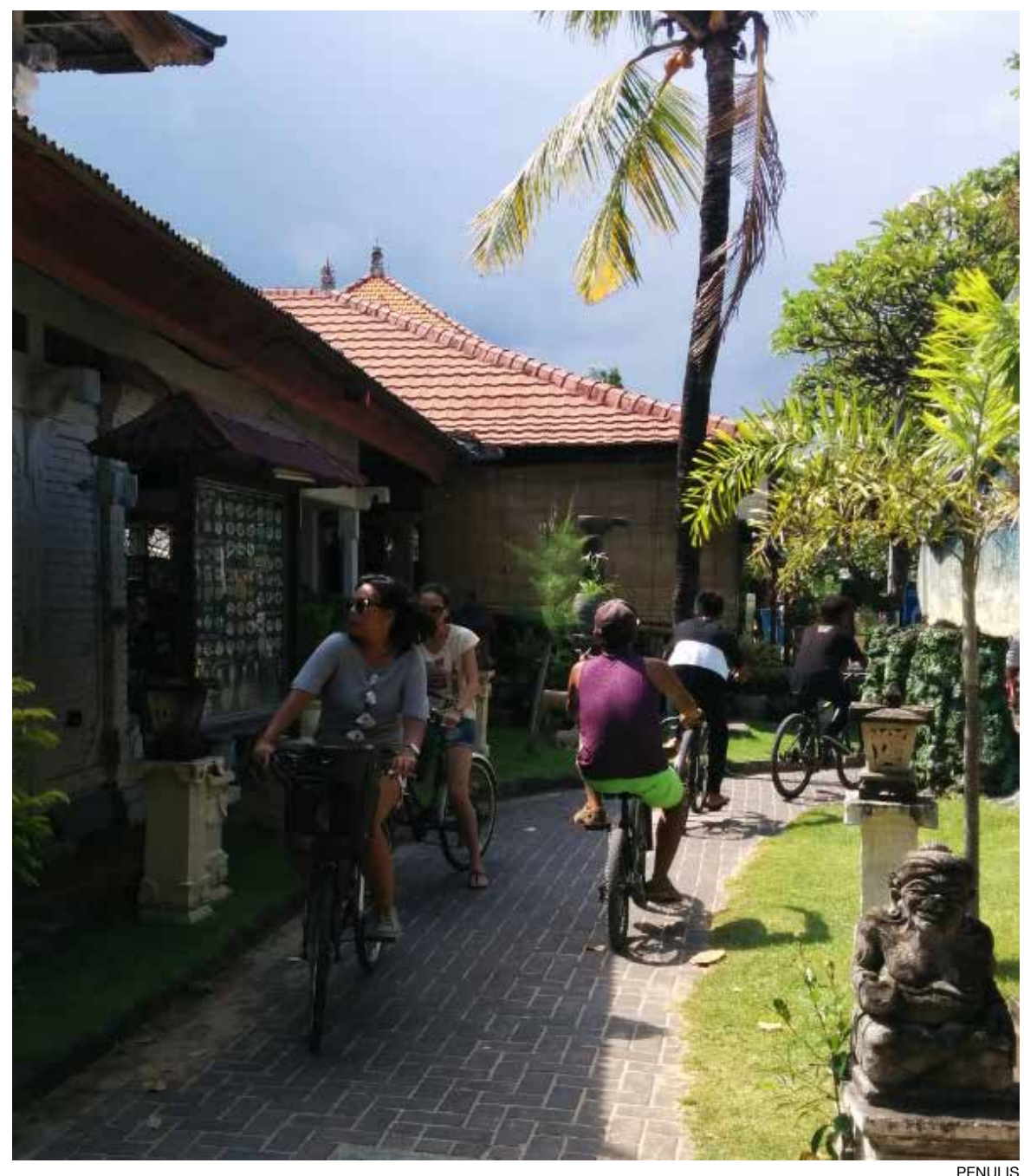

Foto 1. Wisatawan sedang mengendarai sepeda di jalur jogging track di Pantai Segara Ayu, Sanur.

pariwisata, persewaan sepeda dan sarana fisik pendukung publik yang berkaitan dengan bersepeda seperti toilet dan shower.

\subsection{Ancillary}

Kelembagaan dalam mendukung cycling tourism di Sanur terdiri dari pemerintah, komunitas masyarakat dan Yayasan Pembangunan Sanur (YPS). Pemerintah dalam hal ini membangun infrastruktur yang memadai untuk pembangunan pariwisata bersepeda dan mengadakan promosi dari kegiatan bersepeda di Sanur dalam berbagai macam event. Komunitas sendiri memberikan advokasi dalam menggerakkan masyarakat untuk bersepeda di 
Sanur melalui pembuatan peta dan mengadakan event bersepeda bersama. Hal ini akan meningkatkan minat wisatawan bersepeda di Sanur. Yayasan Pembangunan Sanur (YPS) sebagai lembaga yang mengurus tentang berbagai macam pembangunan di Sanur yang melibatkan pemerintah, investor, dan masyarakat, juga turut serta dalam mempromosikan wisata bersepeda melalui event tahunan Sanur Village Festival dan pembuatan peta jalur bersepeda.

\section{Perencanaan Pariwisata Bersepeda}

Perencanaan tentang wisata bersepeda bisa dibuat dengan mengacu pada beberapa regulasi yang ada. UU No 22 Tahun 2009 tentang Lalu Lintas dan Angkutan Jalan menyatakan bahwa setiap jalan yang digunakan untuk lalu lintas umum wajib dilengkapi dengan perlengkapan jalan berupa fasilitas untuk sepeda, pejalan kaki, dan penyandang cacat (pasal 25). Diperkuat dengan menyatakan bahwa fasilitas pendukung penyelenggaraan lalu lintas dan angkutan jalan meliputi lajur sepeda (Pasal 45) dan pemerintah harus memberikan kemudahan berlalu lintas bagi pesepeda. Pada pasal 62 selanjutnya pesepeda berhak atas fasilitas pendukung keamanan, keselamatan, ketertiban, dan kelancaran berlalu lintas.

Denpasar sendiri masuk dalam zona wilayah perkotaan yang semestinya memperhatikan mengenai penyediaan jalur khusus sepeda bagi pengguna jalan di wilayahnya. Di dalam Perda RTRW Kota Denpasar No 27 Tahun 2011 Tentang Rencana Tata Ruang Wilayah Kota Denpasar tahun 20112031. Dalam Pasal 20 mengenai prioritas keselamatan dan kenyamanan bagi pengguna jalan khususnya pejalan kaki dan pengendara sepeda melalui jalur khusus. Selain itu, juga dinyatakan bahwa untuk penyediaan dan pemanfaatan sarana dan prasarana perkotaan perlu disediakan jalur sepeda (Pasal 35).

Sanur dalam hal ini Desa Sanur termasuk dalam Wilayah Perencanaan Kawasan Strategis Sanur mencakup tiga desa/kelurahan di Kecamatan Denpasar Selatan, mencakup Desa Sanur Kaja, Kelurahan Sanur, Desa Sanur Kauh (Pasal 5). Kawasan Strategis ini diatur berdasarkan Rencana Tata Ruang Wilayah Kota Denpasar Perwali No 27 Tahun 2011 Kemudian dijabarkan dalam peraturan zonasi kawasan yang lebih rinci yakni Rencana Tata Ruang Kawasan Strategis Sanur Perwali No o6 Tahun 2013. Perencanaan dan pengaturan sepeda diatur dalam aturan zonasi karena perencanaan yang bersifat lebih mikro/detail.

Pemerintah Kota Denpasar melalui Peraturan Walikota (Perwali) No. 6/2013 mengenai Rencana Rinci Kawasan Strategis Sanur pada pasal 35, jalur sepeda diizinkan dalam kegiatan pertanian berbasis ekowisata. Jalur sepeda bersamaan ditetapkan dengan meliputi kegiatan lain seperti rekreasi dan wisata agro, fasilitas penunjang rekreasi, jogging track, industri kecil, 
kolam pancing, sarana outbond, panggung kesenian, rumah makan, taman rekreasi, perdagangan souvenir, perdagangan hasil pertanian, perdagangan tanaman hias, workshop kerajinan, parkir. Artinya jalur sepeda masuk dalam kegiatan yang bisa dilakukan dalam kegiatan ekowisata. Jalur sepeda terdiri dari empat jenis jalur yang diatur dalam Perwali, yakni jalur pantai, jalur kerja, jalur pedesaan dan permukiman dan jalur persawahan, sedangkan satu jalur merupakan jalur pengembangan baru berkaitan dengan proyek revitalisasi Pantai Sindhu dan Pantai Karang. Kelima jalur ini adalah jalur yang dikembangkan oleh beberapa komunitas untuk bisa dikenal dan dijelajahi oleh wisatawan bersepeda maupun masyarakat di Kota Denpasar.

Untuk lebih lengkap mengenai pembangunan jalur sepeda berdasarkan hierarki dari pemerintah pusat hingga daerah dan destinasi pariwisata bisa dilihat pada Gambar 1.

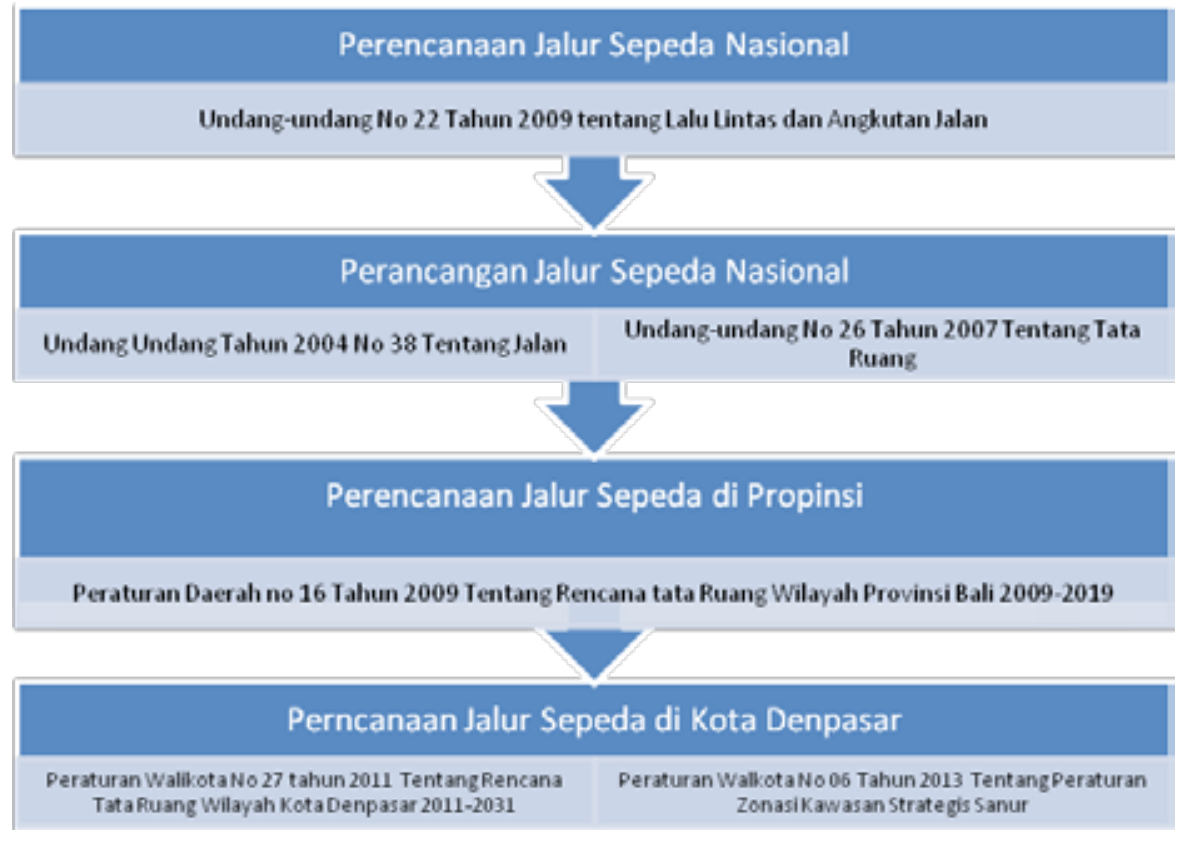

Gambar 1Hieraki Perencanaan dan Perancangan Jalur Sepeda di Destinasi Pariwisata Sanur

(Sumber : Diolah dari beberapa sumber)

Dalam desain perencanaan jalur sepeda di Destinasi Pariwisata Sanur, telah dibuat empat jenis jalur yang sesuai dengan Peraturan Kawasan Strategis Sanur ditambah dengan satu jalur baru sebagai pengembangan dari keempat jalur yang sudah dibuat terlebih dahulu. Sesuai dengan Peraturan Zonasi Kawasan Strategis Sanur yakni jalur pantai/jogging track, jalur permukiman dan pedesaan, jalur persawahan, dan jalur kerja serta jalur pengembangan baru. Selengkapnya mengenai jalur bersepeda lihat Tabel 1. 
Tabel 1 Perbandingan Jalur Bersepeda di Destinasi Pariwisata Sanur

\begin{tabular}{|c|c|c|c|}
\hline $\begin{array}{l}\text { Jalur } \\
\text { Sepeda }\end{array}$ & $\begin{array}{c}\text { Spesifikasi } \\
\text { Jalur }\end{array}$ & $\begin{array}{l}\text { Potensi Jalur } \\
\text { Sepeda }\end{array}$ & Permasalahan \\
\hline Jalur Pantai & $\begin{array}{l}\text { Panjang } 8,2 \mathrm{~km} \\
\text { Waktu tempuh : } \\
32 \text { menit; kecepatan } \\
15 \mathrm{~km} \text { tanpa henti dan } \\
\text { hambatan } \\
\text { Waktu tempuh penulis } \\
1 \text { jam } 10 \text { menit }\end{array}$ & $\begin{array}{l}\text { - Jalur favorit wisa- } \\
\text { tawan } \\
\text { - Panorama pantai yang } \\
\text { indah } \\
\text { - Dekat pusat akomo- } \\
\text { dasi } \\
\text { - Banyak lokasi wisata } \\
\text { dan fasilitas pen- } \\
\text { dukung } \\
\text { - Aman dari kendaraan } \\
\text { - Banyak penyewaan } \\
\text { sepeda } \\
\text { - Kontur lajur rata, ti- } \\
\text { dak melelahkan. }\end{array}$ & $\begin{array}{l}\text { - Jalur sempit, sharing } \\
\text { dengan pejalan kaki } \\
\text { - Konflik ruang antara } \\
\text { pesepeda dengan } \\
\text { pejalan kaki dan pen- } \\
\text { gusaha } \\
\text { - Kendaraan masuk ke } \\
\text { jalur jogging track } \\
\text { - Portal sepeda meng- } \\
\text { hambat laju sepeda } \\
\text { - Polisi tidur di beber- } \\
\text { apa jalur antara hotel } \\
\text { dengan pantai } \\
\text {-B anyak belokan yang } \\
\text { tidak terlihat }\end{array}$ \\
\hline $\begin{array}{l}\text { Jalur Kerja } \\
\text { dan Berekrea- } \\
\text { si }\end{array}$ & $\begin{array}{l}\text { Panjang } 9,9 \mathrm{~km} \\
\text { Waktu tempuh } 39,8 \text {, } \\
\text { kecepatan } 15 \mathrm{~km} \text { tanpa } \\
\text { henti dan hambatan } \\
\text { Waktu tempuh penulis } \\
2 \text { jam } 13 \text { menit }\end{array}$ & $\begin{array}{l}\text { - Banyak fasilitas pen- } \\
\text { dukung wisata } \\
\text { - Terdapat lajur sepeda } \\
\text { - Terdapat papan pen- } \\
\text { tujuk sepeda } \\
\text { - Peta Informasi Pari- } \\
\text { wisata } \\
\text { - Banyak penyewaan } \\
\text { sepeda } \\
\text { - Kontur jalan baik ter- } \\
\text { buat dari aspal halus, } \\
\text { tidak melelahkan } \\
\text { - Jalur mudah dilalui }\end{array}$ & $\begin{array}{l}\text { - Lajur sharing dengan } \\
\text { jalan umum } \\
\text { - Tidak ada pembataas } \\
\text { antara lajur dengan } \\
\text { jalan umum } \\
\text { - Penyerobotan lajur } \\
\text { oleh kendaraan lain } \\
\text { - Garis marka lajur mu- } \\
\text { lai pudar } \\
\text { - Keluar masuk kenda- } \\
\text { raan memotong laju } \\
\text { pesepeda } \\
\text { - Tidak ada toilet, } \\
\text { shower, dan kamar } \\
\text { ganti umum } \\
\text { - Jalur panjang, diper- } \\
\text { lukan stamina yang } \\
\text { baik untuk melalui- } \\
\text { nya }\end{array}$ \\
\hline $\begin{array}{l}\text { Jalur Perde- } \\
\text { saan dan Per- } \\
\text { mukiman }\end{array}$ & $\begin{array}{l}\text { Panjang } 9,8 \mathrm{~km} \\
\text { Waktu tempuh } \\
39,59 \text { menit, } \\
\text { kecepatan } 15 \mathrm{~km} \text {, tan- } \\
\text { pa henti dan hambatan } \\
\text { Waktu tempuh penulis } \\
\text { 1 jam } 55 \text { menit }\end{array}$ & $\begin{array}{l}\text { - Jalur yang mengede- } \\
\text { pankan budaya } \\
\text { - Jalur yang banyak } \\
\text { melalui permukiman } \\
\text { penduduk, wisatawan } \\
\text { bisa berinteraksi den- } \\
\text { gan warga } \\
\text { - Banyak terdapat pura } \\
\text { dan peninggalan } \\
\text { bersejarah }\end{array}$ & $\begin{array}{l}\text { - Tidak ada toilet, } \\
\text { shower dan kamar } \\
\text { ganti umum } \\
\text { - Masuk gang sempit } \\
\text { dan hanya bisa dilalui } \\
\text { oleh dua kendaraan } \\
\text { sepeda motor } \\
\text { - Kurang fasilitas wisa- } \\
\text { ta dan pendukung } \\
\text { bersepeda } \\
\text { - Banyak tikungan yang } \\
\text { tidak terlihat }\end{array}$ \\
\hline
\end{tabular}




\begin{tabular}{|c|c|c|c|}
\hline $\begin{array}{l}\text { Jalur Per- } \\
\text { sawahan }\end{array}$ & $\begin{array}{l}\text { Panjang } 4,9 \mathrm{~km} \\
\text { Waktu tempuh } \\
\text { 19,65 menit, kecepatan } \\
15 \mathrm{~km} \text {, tanpa henti dan } \\
\text { hambatan } \\
\text { Waktu tempuh penulis } \\
: 45 \text { menit }\end{array}$ & $\begin{array}{l}\text { - Jalur hijau, termasuk } \\
\text { ruang terbuka hijau, } \\
\text { udaranya bersih } \\
\text {-Pemandangan sawah } \\
\text { yang unik dibanding- } \\
\text { kan dengan wisata } \\
\text { pantai } \\
\text {-Tidak terlalu ramai } \\
\text { dengan kendaraan }\end{array}$ & $\begin{array}{l}\text { - Jalan tanah dan ha- } \\
\text { nya mengalami per- } \\
\text { kerasan alami } \\
\text { - Jauh dari pusat wisata } \\
\text { - Jalan kadang membi- } \\
\text { ngungkan terutama di } \\
\text { jalur subak yang ban- } \\
\text { yak cabang jalan } \\
\text { - Tidak ada rambu lalu } \\
\text { lintas } \\
\text { - Melewati jalan kecil } \\
\text { dan belokan yang } \\
\text { tidak terlihat } \\
\text { - Tidak ada penerangan } \\
\text { jalan } \\
\text { - Banyak terjadi kon- } \\
\text { versi lahan, mengu- } \\
\text { rangi pemandangan } \\
\text { sawah } \\
\text { - Tidak ada toilet, } \\
\text { shower dan kamar } \\
\text { ganti umum }\end{array}$ \\
\hline $\begin{array}{l}\text { Jalur } \\
\text { Pengemban- } \\
\text { gan Baru } \\
\text { Pantai Sin- } \\
\text { du-Pantai } \\
\text { Karang }\end{array}$ & $\begin{array}{l}\text { Panjang } 3,2 \mathrm{~km} \\
\text { Waktu tempuh } \\
13 \text { menit, kecepatan } 15 \\
\text { km, tanpa henti dan } \\
\text { hambatan } \\
\text { Waktu tempuh penulis } \\
25 \text { menit }\end{array}$ & $\begin{array}{l}\text {-Jalur memiliki fasil } \\
\text { itas memadai untuk } \\
\text { bersepeda } \\
\text { - Berjarak pendek, co- } \\
\text { cok untuk turis dewa- } \\
\text { sa dan anak-anak } \\
\text { - Pemandangan pantai, } \\
\text { aktivitas masyarakat, } \\
\text { pemukiman dan pura } \\
\text { dalam satu jalur } \\
\text { - Terintegrasi dengan } \\
\text { transportasi publik } \\
\text { Trans Sarbagita dan } \\
\text { pol taksi }\end{array}$ & $\begin{array}{l}\text { - Jalur pendek dan } \\
\text { waktu tempuh singkat } \\
\text { - Belum siap dalam pe- } \\
\text { nataan karena masih } \\
\text { banyak tempat-tem- } \\
\text { pat kumuh } \\
\text { - Masuk gang sempit } \\
\text { yang harus berbagi } \\
\text { dengan sepeda motor } \\
\text { dari dua arah }\end{array}$ \\
\hline
\end{tabular}

Jika melihat pada Tabel 1, perbandingan jalur sepeda masih banyak terdapat permasalahan dari semua jalur. Jalur Pantai merupakan jalur yang paling lengkap dalam hal fasilitas dan paling mempunyai tingkat kenyamanan dan keamanan yang baik dibdaningkan dengan jalur lain, karena tidak bersama dengan kendaraan lain dalam penggunaanya. Jalur kerja sebagai jalur yang diharapkan bisa mengajak masyarakat lokal untuk bersepeda dari rumah hingga ke tempat kerja, masih melalui gang sempit dengan belokan yang tidak terlihat. Hal yang membahayakan bagi wisatawan jika melalui jalur ini. Pada Jalur Perdesaan dan Permukiman, wisatawan akan melihat beberapa permukiman tradisional warga Sanur, sehingga bisa berinteraksi dengan masyarakat lokal. Fasilitas pendukung masih kurang di jalan ini dan jalur ini semua masih menggunakan jalur bersama dengan kendaraan lain. Pada Jalur Persawahan, potensi sawah menjadi sentral pada 


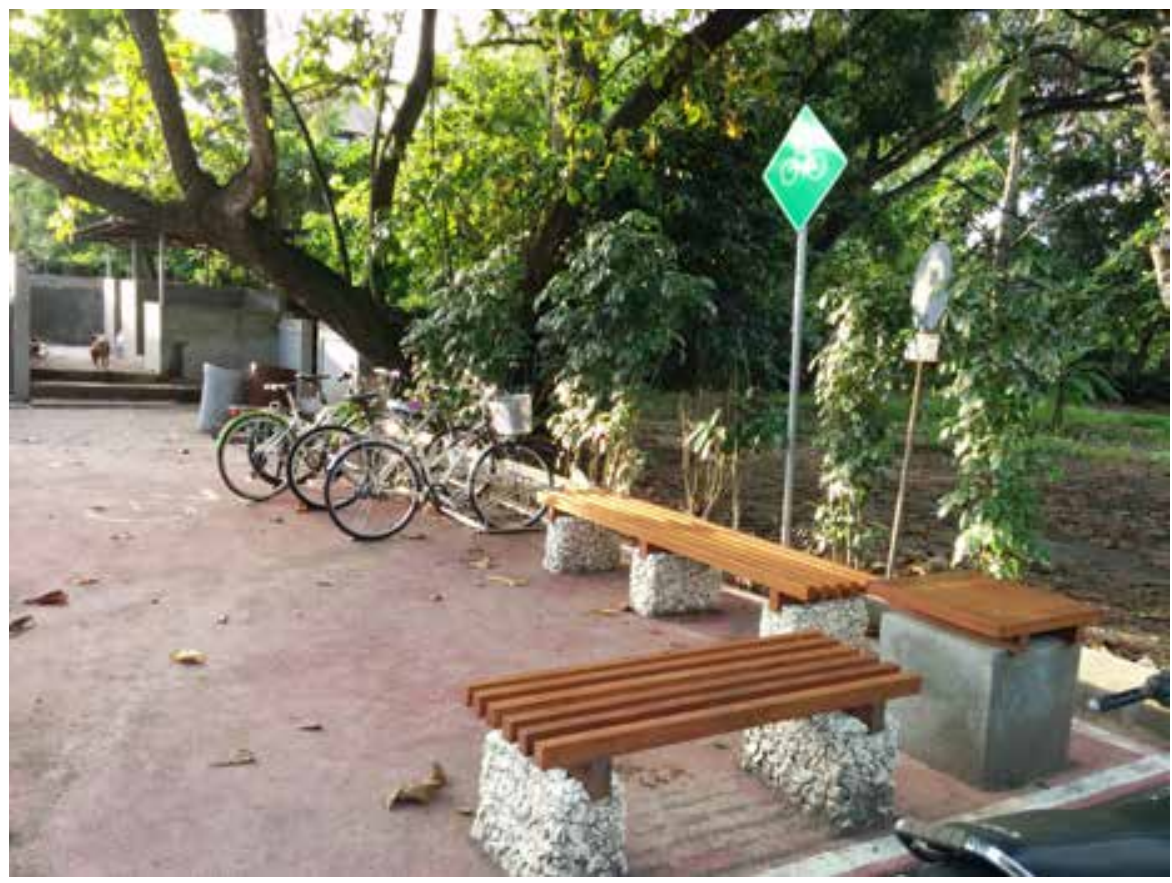

PENULIS

Foto 2. Fasilitas parkir sepeda, rambu sepeda, toilet, dan tempat istirahat bagi pengendara sepeda di jalur pengembangan baru, Pantai Karang, Sanur.

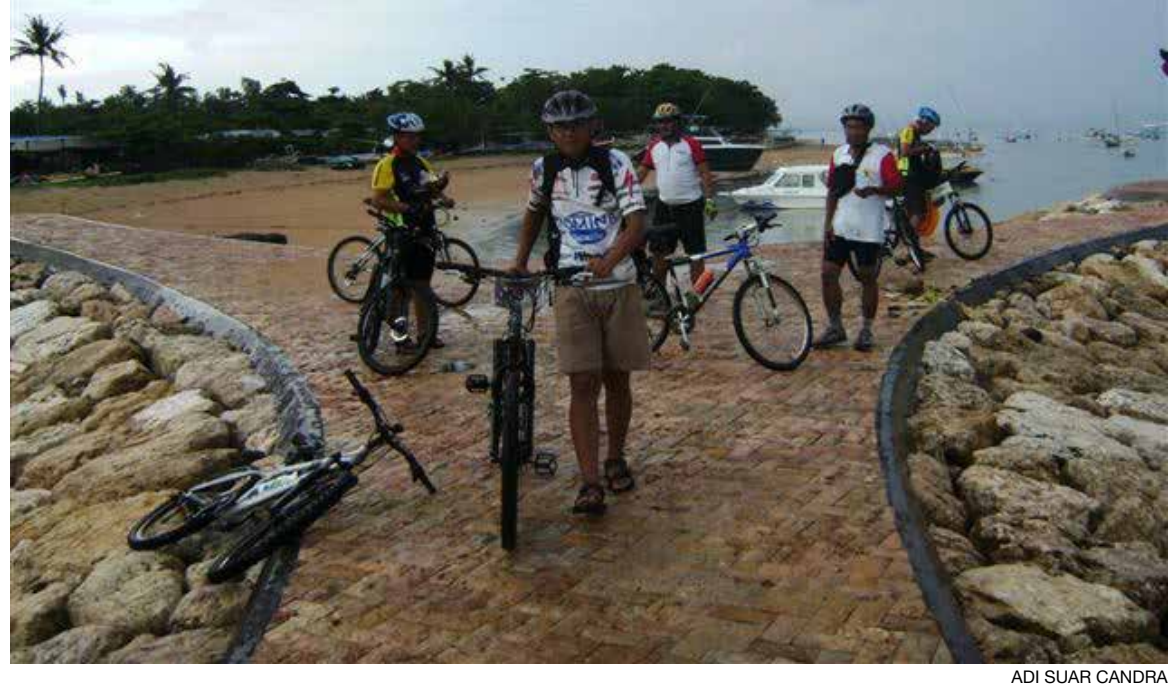

Foto 3. Wisatawan domestik bersepeda di jalur jogging track Sanur. 


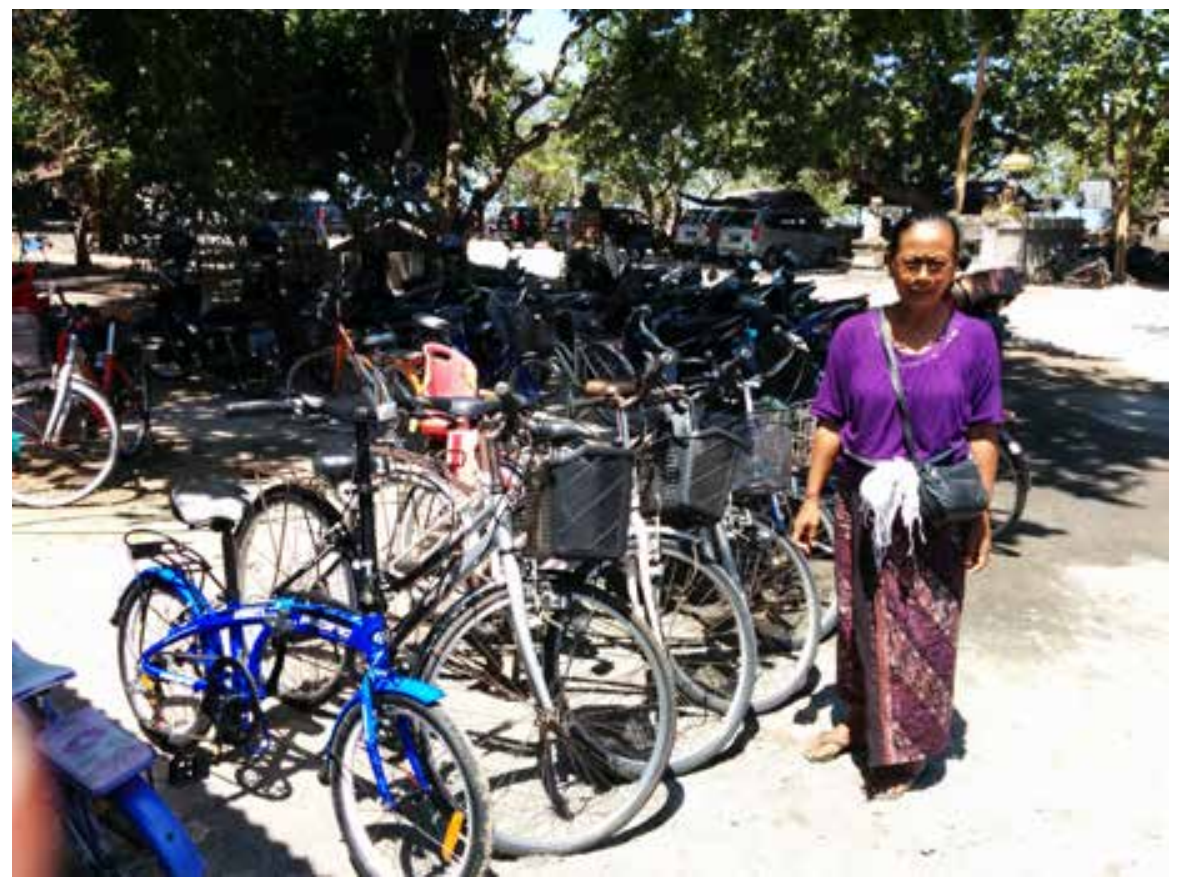

KOMANG WIRAWAN

Foto 4. Bu Sri, pemilik persewaan sepeda di Pantai Karang Sanur.

jalur ini, namun kondisi jalan yang tidak baik karena terbuat dari tanah dan batu, akan menyulitkan wisatawan, terlebih pada keadaan basah. Jalur terakhir adalah Jalur Pengembangan Baru yang berjarak pendek, tetapi memiliki fasilitas yang memadai, dari toilet hingga pendukung bersepeda lainnya. Jalur ini diharapkan menjadi sebuah katalis untuk keempat jalur lain sehingga memperoleh barbagai macam pembangunan fisik untuk pemenuhan kebutuhan para pengendara sepeda.

Dari kesemua jalur, seluruhnya melewati potensi-potensi utama Destinasi Pariwisata Sanur. Kurangnya promosi membuat masyarakat dan wisatawan tidak mengetahui semua jalur bersepeda. Wisatawan hanya mengetahui jalur pantai, sehingga jalur ini terkadang sangat padat dan mengganggu pejalan kaki di jogging track terutama pada sabtu sore dan minggu pagi, terlebih pada musim liburan sekolah.

Dalam suatu perencanaan, promosi atau pengenalan mengenai perencanaan tersebut, penting dilakukan. Agar perencanaan yang dibuat bisa menjadi suatu yang berguna di dalam wilayah tersebut. Dalam implementasi dan promosi wisatawan bersepeda ada beberapa hal yang telah dilakukan di Destinasi Pariwisata Sanur, baik oleh pemerintah, komunitas, maupun pihak lain yang mempunyai perhatian terhadap pariwisata bersepeda seperti:

a. Sanur Village Festival mengadakan secara rutin tur sepeda/fun bike 


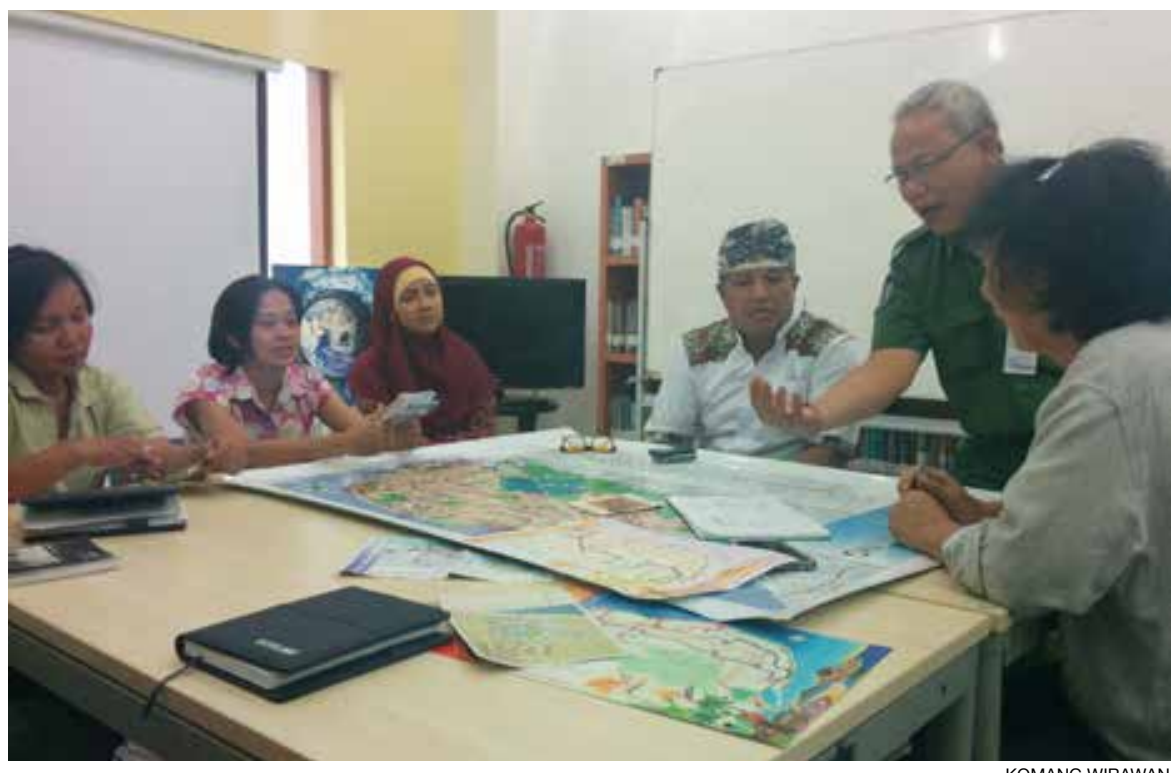

Foto 5. FGD Peta Sepeda Bersama ECO Sanur PU dan Konsultan.

bersama dengan para wisatawan untuk mengenalkan pariwisata bersepeda.

b. Pembuatan jalur pengembangan baru, hal ini digunakan untuk menjadi katalis untuk memperluas jalur sepeda pada masa yang akan datang. Jalur ini sebagai jalur sepeda ideal beserta dengan fasilitas pendukung bersepeda agar wisatawan merasa nyaman dan aman dalam berkegiatan sepeda (Foto 2).

c. Pembuatan informasi jalur sepeda yang ditempatkan di titik-titik yang strategis, Hal ini akan semakin meningkatkan minat wisatawan untuk bersepeda di dalam destinasi pariwisata.

d. Pencetakan petajalur sepedayang disebarkan kepada hotel dan wisatawan seperti yang dilakukan oleh ECO Sanur. Ada juga pembuatan peta jalur sepeda secara mandiri oleh hotel yang disebarkan kepada wisatawan yang ingin beraktivitas bersepeda, seperti pada Hotel Fairmont yang baru dibuka pada akhir tahun 2014 sebagai bagian dari promosi .

e. Ada beberapa usaha seperti restaurant yang memberikan diskon bagi wisatawan yang menggunakan sepeda jika berbelanja ke tempat usahanya.

f. Paket tour sepeda sebagai bagian dari fasilitas hotel seperti di Hotel Santrian Sanur dan Prana Hotel, dimana pihak hotel menyediakan pemandu untuk aktivitas mengelilingi Sanur dengan menggunakan sepeda untuk melihat Sanur dari berbagai potensi wisatanya. 


\section{Penutup}

Destinasi Pariwisata Sanur dalam mengembangkan pariwisata bersepeda sangat potensial melihat dari potensi yang ada. Dari komponen $4 A$ yang dijelaskan, hampir kesemua elemen mendukung pariwisata bersepeda sebagai sebuah aktivitas wisata yang bisa memberikan manfaat bagi destinasi. Komponen yang terdiri dari Atrraction, Accessibility, Amenities, dan Ancillary kesemuanya mendukung usaha dalam perkembangan pariwisata bersepeda. Sebagai jenis pariwisata yang berkembang di dunia sudah seharusnya dikembangkan oleh beberapa destinasi pariwisata lain. Pariwisata bersepeda dalam penerapannya mampu memberikan dampak yang kecil dalam hal penggunaan energi fosil dan dampak dari penggunaannya terhadap lingkungan. Bersepeda di Sanur bukan hanya hal yang mudah dilakukan tetapi sangat murah dan menyenangkan.

Dalam pembangunan pariwisata dibutuhkan suatu perencanaan pariwisata tidak terkecuali dengan pariwisata bersepeda. Adanya jalur bersepeda yang bermula dari komunitas hingga menjadi suatu kebijakan di dalam Perda adalah sebuah langkah yang baik dalam memajukan pariwisata bersepeda. Selanjutnya pembangunan sarana dan prasarana pendukung wisatawan pariwisata bersepeda sangat mutlak dilakukan, mengingat banyak jalur bersepeda yang tidak disertai dengan fasilitas bersepeda yang memadai. Diharapkan semua elemen dan potensi yang ada di Destinasi Pariwisata Sanur mendukung pariwisata ini, baik pemerintah, komunitas, pelaku usaha dan masyarakat harus memberikan kontribusi nyata agar wisatawan bisa beralih menggunakan sepeda sebagai moda utama di destinasi untuk mewujudkan pariwisata berkelanjutan di Destinasi Pariwisata Sanur.

\section{Ucapan Terima Kasih}

Puji syukur penulis panjatkan kehadapan Ida Sang Hyang Widhi Wasa, Tuhan Yang Maha Esa, karena atas Asung Kerta Wara Nugraha-Nya jurnal ilmiah pariwisata ini dapat terwujud. Terima kasih kepada seluruh masyarakat Sanur yang telah membantu memberikan informasi yang mendukung penelitian ini. Semoga penelitian ini bemanfaat bagi dunia praktis dan akademis.

\section{Daftar Pustaka}

Broadaway, S. 2012. Bicycle Tourism an Rural Community Development: an Asset Based Approach. Master of Science. Kansas: Kansas State University.

Gilbert, E. 2006. Eat Pray Love. London: Penguin Books

Guiver, J. Lumsdon, L., Weston, R. 2008. Traffic Reduction at Visitor Attractions: the Case of Hadrian's Wall. London: Journal of Transport Geography

Lumsdon, L. 2000. Transport and Tourism: Cycle Tourism - A Model for Sustainable Development? Journal of Sustainable Tourism. Vol. 8 no. 5, pp. 361-77. 
Pucher,J., Buehler,R. 2012. City Cycling. Massachusetts: The MIT Press.

UNEP UNWTO. Making Tourism More Sustainable: A Guide for Policy Makers. New York: UNEP UNWTO

\section{Undang-undang dan Peraturan}

Undang-Undang Nomor 38 Tahun 2004 Tentang Jalan

Undang-Undang No 26 Tahun 2007 Tentang Penataan Ruang

Undang-Undang Nomor 10 Tahun 2009 tentang Kepariwisataan

Undang-Undang Nomor 22 Tahun 2009 Tentang Lalu Lintas dan Angkutan Barang. Peraturan Daerah No 26 Tahun 2009 Tentang Rencana Tata Ruang Wilayah Provinsi Bali Tahun 2009-2019

Peraturan Walikota Nomor 27 Tahun 2011 Tentang Rencana Tata Ruang Wilayah Kota Denpasar Tahun 2011-2031.

Peraturan Walikota Denpasar Nomor 6 Tahun 2013 Tentang Peraturan Zonasi Kawasan Strategis Sanur.

\section{Profil Penulis}

Penulis adalah alumni Program Studi Magister Kajian Pariwisata, Program Pascasarjana Universitas Udayana. Ia menyelesaikan pendidikan strata satu di Program Studi Perencanaan Wilayah dan Kota, Universitas Gadjah Mada. Kini ia aktif sebagai assisten pengajar di S1 Perencanaan Wilayah dan Kota, Universitas Hindu Indonesia. Di institusi yang sama aktif sebagai pengurus dan peneliti di Pusat Studi Pembangunan Perkotaan dan Wilayah. Terlibat aktif dalam pengembangan peta sepeda dan peta hijau di Sanur bersama ECO Sanur dan Yayasan Pembangunan Sanur. 